\title{
最新の整形外科理学療法テクニック
}

一痛みと理学療法テクニックー

\section{Latest Orthopedic Physical Therapy Techniques: Pain and Physical Therapy Technique}

\section{高田 治実 ${ }^{1)}$}

HARUMI TAKADA ${ }^{1)}$

1) Clinical Walfare College: 3-32-21 Shakujiidai, Nerima, Tokyo 177-0045, Japan

Rigakuryoho Kagaku 23(2): 329-334, 2008. Submitted Nov. 15, 2007.

ABSTRACT: The Myo- (muscle) Tuning Approach has come to be known as MTA. I report on the basic therapy principles of this technique, its suitability, therapy procedures and assessment. I also report on therapy methods for orthopedic problems: exercise pain, hernia, osteoarthritis, frozen shoulder, range of motion disorders, etc.

Key words: pain, myo-tuning approach, muscle tone

要旨：MTAは，筋（myo）を調整（tuning）するアプローチという意味で命名している。このテクニックの基本的治 療原理を述べ, 適応, 治療手技, 評価について述べる。また, 各整形外科疾患別（運動痛，ヘルニア，変形性関節症， 五十肩，関節可動域障害など）の治療法についても述べる。

キーワード : 疼痛, マイオチューニングアプローチ, 筋緊張

1) 臨床福祉専門学校 : 東京都練馬区石神井台3-35-21（干177-0045）

受付日 2007年11月 15 日 


\section{I.はじめに}

読者の皆樣は, 痛みの訴えが強いために理学療法 (以 下PT）が難渋したり，対応できなかった経験はあるだ ろうか? それらの痛みを改善し, 訓練効果を向上させ る技術を持っているだろうか? そのような患者に, 読 者の皆様は「患者が痛いと言って訓練をしない，あの 患者はモチベーションが無い」「痛みがあるから PT を 十分に施行できない」などと, PT効果が向上しない原 因を自分のPTテクニック不足ではなく, 患者や痛みの 所為にしていないだろうか。本稿で紹介するテクニッ クでは，多くの痛みや瘏れを改善でき，PT効果を飛躍 的に向上できる。

筆者は, 痛み, 瘏れ, 筋緊張異常, 中枢・未梢神経 障害後遺症などを改善するマイオチューニングアプロー チ（MTA）を提唱し，理論と技術を構築してきた。特 に, MTAの理論と技術は, 平成 18 年度文部科学省委託 事業, 「理学療法士養成課程へのマイオチューニングア プローチ導入のための教育プログラム作成」という委 託研究の中で再構築された。委託事業では, 東京医科 歯科大学の佐藤達夫名誉教授, 新潟大学医学部の熊木 克治名誉教授, 順天堂大学医学部の坂井建雄教授に実 施委員として御助言を頂いた。また, 東京医科大学 (神 経解剖学）の山田仁三主任教授にはアドバイザーとし て理論に関するご指導を頂き, MTAの教本 ${ }^{1)}$ とDVDを 作成した。

本稿では，上記委託事業の成果に基づきMTAの基本 的な理論および手技を紹介し，整形外科疾患に対する MTAを紹介する。

\section{MTAとは}

MTAは，筋（myo）を調整（tuning）するアプローチ という意味で名付けた。現在, MTA は神経生理学的現 象を利用し, 主に筋（稀に皮膚から皮下組織）が原因 で生じている症状を改善すると共に, 筋を活性化させ る治療的手技であると定義している。MTAの目的は， 痛み, 痺れ, 筋緊張の異常および筋の活動効率を改善 することによって, 関節可動域 (Range of Motion : ROM) や運動能力を向上させ, 日常生活動作 (Activities of Daily Living : ADL) および生活の質（Quality of Life : QOL）を 高め，精神的苦痛を和らげることである。

痛みは, 運動神経や交感神経を興奮させると共に力 テコラミンの分泌を促進させ血管を収縮させ，図 1 に 示すような悪循環を起こす。その結果，痛み，痺れ，筋
緊張の異常などの症状が増悪する。それらの症状は, 運動機能やモチベーションを低下させ，理学療法の阻 害因子となり, 効率的な ROM 訓練, 筋力強化訓練, ADL 訓練あるいは歩行訓練などを困難にする。また，中枢 および末梢神経の障害による筋の活動効率低下は, 運 動麻痺を助長させ理学療法の阻害因子となることが多 い。筋が原因で起こるそれらの阻害因子を改善できれ ば，難渋していた訓練が可及的速やかに可能となり， 理学療法の質およびモチベーションが顕著に向上する。 その結果，治療効果が飛躍的に高まりゴール達成まで の期間を短縮できる。MTAでは，前記の阻害因子を触 圧覚受容器, 侵害受容器および固有受容器を刺激し, 神経生理学的現象を誘発することによって改善すると 推測している。

実際に，筆者らのデータ 2,3)では，MTAにより痛み， 瘏れ，筋緊張の異常などが即時的に改善し，筋力，筋 積分值および関節可動域が顕著に増加している。その ため, 整形外科疾患, 内科疾患および脳血管障害後遺 症による運動麻痺などの中枢性疾患まで幅広い適応が ある。

MTAは，運動療法の中で施行することを基本とする 手技でもあり, 症状を改善しながら運動療法を施行す ることによって筋の収縮機能を活性化させ伸張機能を 向上させる自動能動的な治療的手技でもある。また, 中心となる基本手技は症状を触圧覚刺激によって改善 する手技であるため, 組織を損傷し症状を悪化させる 危険性が少ない手技でもある。

\section{III. 本書で使用するMTAの専用の用語とその意味}

1. 再現症状：(1)患者が訴えている症状と種類および 部位が全く同じ症状。(2)原因筋線維の刺激により 再現できる症状（再現痛，再現痺れなどがある）。

2. 原因筋：(1)症状の原因になっている筋。(2)刺激に より再現症状を生じる筋。(3)身体の動きを抑制し ている筋。

3. 原因筋線維 : (1)原因筋に含まれる筋線維。(2)症状 の原因であり治療対象となる筋線維。(3)刺激によ り再現症状を生じる筋線維。(4)身体の動きを抑制 している筋線維。

4. 抑制部位：刺激により再現症状を改善できる部位。

\section{MTAの基本的治療原理}

MTA で関与すると推測される $2 つ の$ 神経生理学的機 
序を以下に概説する。

1. 痛み, 疩れ, 筋緊張六進などの症状を抑制する神経生 理学的機序

本機序では, 筋の破壊や変性症などにより侵害受容 器が刺激されて発生する痛覚神経線維のインパルスを, 脳に到達する前に消失させることによって, 痛み, 痺 れ, 筋緊張㐫進などの症状が改善寸ると推測している。 言い換えれば，徒手で行う神経ブロック療法とも言え る。本機序は, 触圧覚受容器および侵害受容器の刺激 によって起こると推測している。

1) 触圧覚受容器の刺激によって起こる神経生理学的 機序

触圧覚受容器の刺激では, 主にゲートコントロール 理論 ${ }^{4,5)}$ が作用し, 痛みが消失すると推測される。本理 論は, 触圧覚神経線維のインパルスの増加により脊髄 後角の膠様質細胞 ( $\mathrm{SG}$ 細胞) が活性化し, 伝達細胞 ( $\mathrm{T}$ 細胞）を通り上位中枢一行く痛覚神経線維のインパル スが抑制され，痛みが改善されるといわれている（図 2)。本理論は, 痛みが起こる部位と同じ皮膚分節の圧 刺激で起こると考えられている。しかし, 触覚の皮膚 分節は，複数の髄節にまたがっていると言われている ため, 痛みが起こる髄節以外の部位を圧迫しても痛み を抑制できる可能性がある。また, 数箇所の圧刺激に より，抑制の加重効果も期待できると推測される。ま た, ソフトで緩やかな触圧覚受容器への刺激は, 交感 神経の活動を減少させるとともに, 副腎髄質からのカ テコラミン分泌量を減少させる6)。カテコラミンは, 交 感神経を活性化させるので, 分泌量が減少すれば交感 神経の活動が低下し, 副交感神経の活動が優位になる 可能性がある。その他, Oscarsonによれば7), 皮膚から の触圧覚刺激により起こったインパルスは， $\alpha$ 運動 ニューロンに対して抑制的に作用し筋緊張が低下寸る 可能性がある。以上述べた 3 つ機序の相乗効果によ り, 痛みなどが改善すると推測される。

2）痛覚刺激によって起こる神経生理学的機序

侵害受容器の刺激では, (1)内因性モルヒネ様物質に よる抑制，(2)下行性疼痛抑制系による抑制，(3)広汎性 侵害抑制調節8) による抑制などが作用し, 痛み, 瘏れ, 筋緊張の異常などの症状が改善されると推測している。 (1)による抑制は, 脳内疼痛抑制系とも呼ばれており痛 み刺激によって内因性モルヒネ椂物質（エンドルフィ ンなど）が脳内で生成され，生体内の受容体と結合し 痛みを抑制する系であり, 強い痛み刺激により発生す ると考えられている。(2)による抑制は, 痛み刺激が中
枢に伝えられた後, 下行性の神経線維によってノルア ドレナリン，セロトニンなどが脊髄後角へ分泌され， 受容体と結合し痛みを抑制する系である。(3)による抑 制は，女る部位の痛みが別の部位への痛み刺激によっ て脊髄後角や三叉神経脊䯣路核で抑制される現象であ り, 抑制効果は強い痛み刺激の方が高いと考えられて いる。

2. 中枢・未梢神経障害による運動障害を改善させる機序 現時点では，2つの機序を推測している。1つは，固 有受容器の刺激によって起こる神経線維のインパルス の増加である。もう1つは, 筋緊張異常や血行障害の改 善結果として生じる末梢神経終末（神経一筋移行部） から放出される神経伝達物質の量の増加およびスライ ディングセオリーの活性化などである。

\section{MTAで作用すると考えられる主な機序}

作用機序は, (1)痛みの悪循環の遮断, (2)筋緊張の改 善, (3)循環不全の改善, (4)筋収縮機能の改善, (5)発痛 物質の患部からの除去, (6)侵害受容器の闇値の改善, (7) 反射性筋肉痛（図3）の改善，8変性や壊死により壊 された組織の再生，などが推測される。

\section{MTAの手技}

MTAの手技は, 以下の5つに大別される。受容器は, 筋を手指で骨の表面に直角に圧迫し，走行に対して直 行するように刺激する。

\section{1. 基本手技}

MTAの中心手技であり，原因筋線維および抑制部位 の両方に触圧覚刺激を加えて施行する。本手技では, 静的施行法あるいは動的施行法を用いて実施する。前 者は, 臥位, 座位, 立位などの静止状態で原因筋線維 および抑制部位に触圧覚刺激を加えることにより症状 を改善する手技である。安静状態で施行できるので梁 部の症状まで改善できる。後者は, 原因筋線維および 抑制部位に触圧覚刺激を加えながら, 再現症状が起こ る動作を行わせ症状を改善する手技であり, 運動療法 として施行する。そのため, 筋の収縮機能および伸張 される機能がより改善し筋機能が向上するため, 筋緊 張や血流がより改善し痛みなどの治療効果が向上寸る と推測される。 
2. MTAストレッチング

基本的には，動的施行法を用いた基本手技によって 症状を改善し, 最後に原因筋線維のセルフストレッチ ングを行う手技である。患者が十分にセルフストレッ チングを行えない場合には, 軽度の自動介助運動によ り痛みが起きない範囲で施行する。

\section{3. 触圧覚刺激と痛覚刺激により施行する手技}

基本手技で症状を改善できない場合に施行する手技 である。原因筋線維には触圧覚刺激を, 抑制部位には 痛覚刺激を加えて施行する。

\section{4. 痛覚刺激により施行する手技}

上記，1.〜3. の手技で症状を改善できない場合に施 行する手技である。強い痛み刺激を原因筋線維に加え て施行する。

5. 中枢および末梢神経麻疩の不全麻㾝や弛緩性麻痺に施 行する手技

動きを活性化させたい筋の固有受容器を, 起始部か ら停止部まで刺激しながら, 視覚, 聴覚にも働きかけ て施行する。

\section{VII. 適 応}

主な適応は，侵害受容性疼痛，末梢および中枢神経

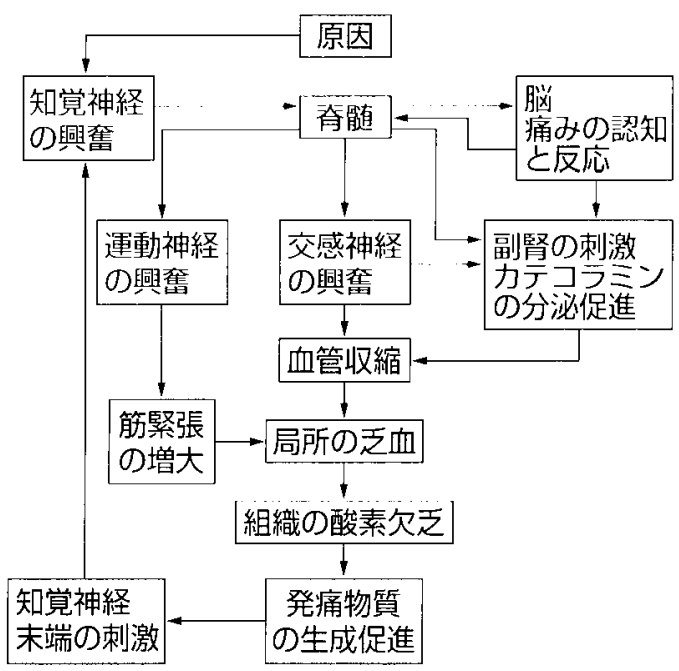

図1 痛みによって起こる生体の変化一痛み (花岡一雄 : 疼痛コントロールABC．日本医師会)
障害による運動障害，筋緊張が原因で起こる絞扼症状 としての痺れと痛みなどである。

\section{VIII. 評 価}

評価の主目的は，筋触察による再現症状を基に原因 筋線維を確定することである。重要な運動検査は，(1) 患者が訴えている症状が出現する動きを自動運動で行 わせ，軽く痛みが出る肢位で再現症状を基に原因筋線 維（部位, 程度, 種類）を確定する。(2)筋力の左右差を 確認する。(3)原因筋線維へ悪影響を与えている連結筋 を確認する。（原因筋の関連筋を軽く圧迫した状態で， 再現症状が起こる動作を行わせ, 症状の変化を確認寸 る)。(4)原因筋線維と推測した筋線維を軽く圧迫した状 態で再現症状が起こる動作を行わせ, 症状の変化を確 認寸る。などである。(5)原因筋の抵抗筋の筋力低下が あるかどうかを確認する。

\section{IX. 整形外科疾患に対するMTAの実際}

以下に，整形外科の一般的な疾患，症状に対する基 本的な施行法を簡単に述べる。なお，原因筋線維は筋 触察により侵害受容器を刺激し再現痛が出現する部位 の笳線維である。

1. 運動時痛

運動時痛は，全て痛みが起こる動作の中で探す。例 えば，歩行の接踵期に起こる痛みであれば，(1)実際に

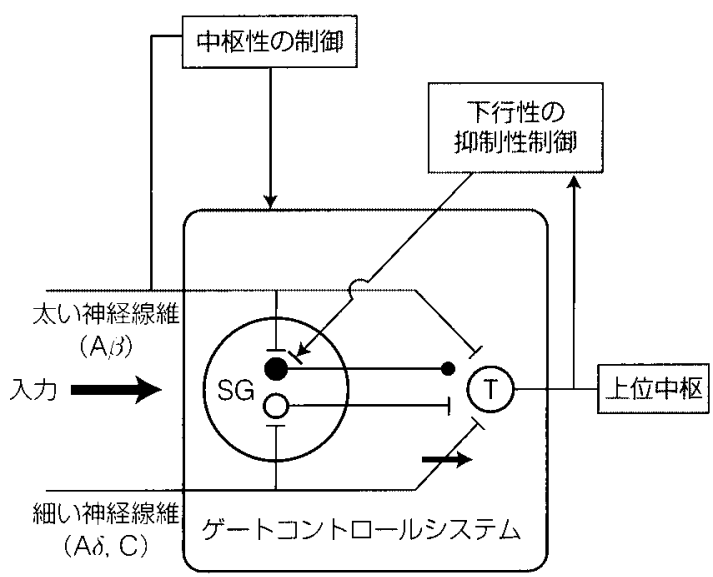

図2 修正されたゲートコントロール理論 (奈良 勲: 標準理学療法学専門分野物理療法学, 第1版, $\mathrm{p} 152$, 医学書院, 東京, 2002より引用) 

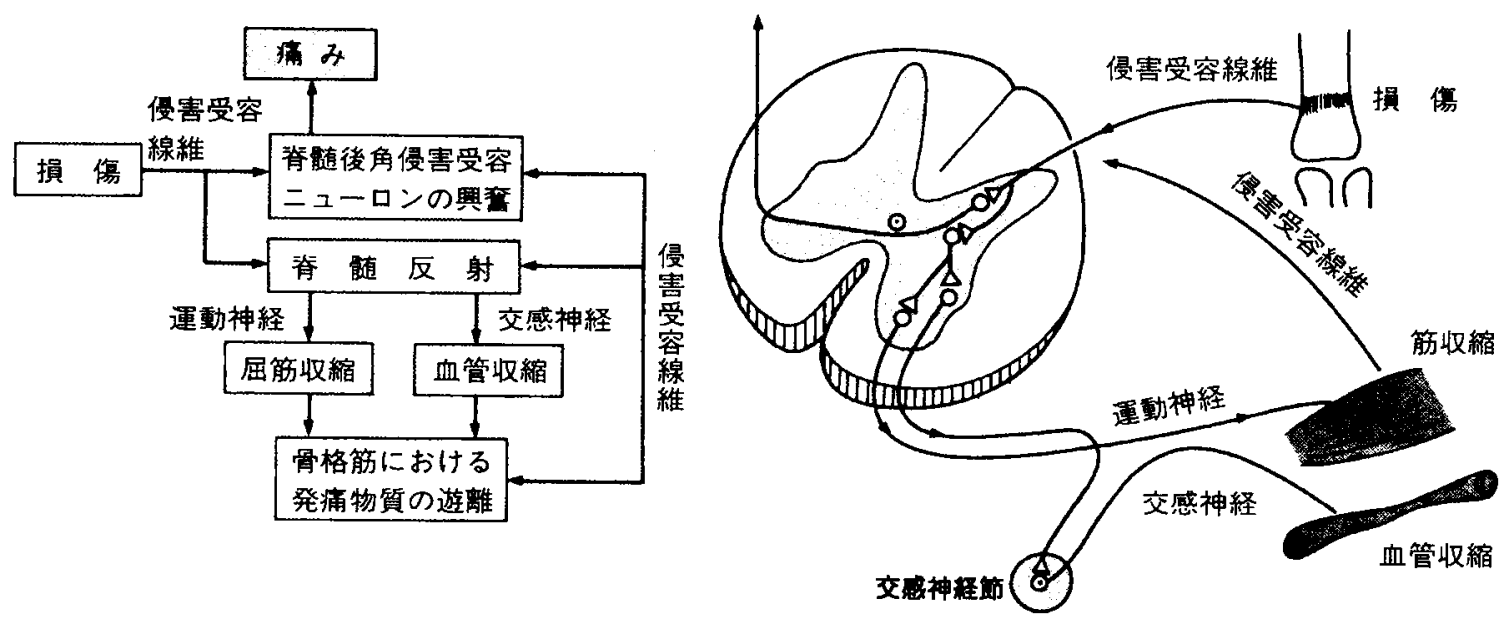

図3 反射性筋肉痛の発生機序

(横田敏勝 : 臨床医のための痛みのメカニズム. 第2版, p101, 南江堂, 東京, 1997より引用)

歩行を行わせ接踵期で再現痛を発生させながら，筋触 察により再現痛が増強する部位を探し，原因筋線維を 確定する。(2)基本手技で痛みを消失させながら前後に 足踏みし, 症状の改善状況を確認する。(3)症状が消失 していたら，基本手技の動的施行法で症状を改善しな がら 5 〜 10 回足踏みさせる。(4)臥位で再現痛を探し基 本手技で改善する。

2. 腰痛, 頚部痛, 腰椎椎間板ヘルニア, 頚椎椎間板ヘル ニア

腰椎椎間板ヘルニアと腰痛は, 同様の方法で治療す る。まず, 腰痛が起こる動作により再現痛を起こした 状態で, 筋触察により原因筋線維を確定し動的施行法 を実施する。その後, 臥位になり筋触察で再現痛を探 し症状を改善する。例えば, 体幹伸展で最長筋に痛み があれば，体幹伸展位で再現痛を起こした状態で筋触 察により再現痛が増強する筋を探し, 基本手技の動的 施行法とMTAストレッチングで再現症状を消失させる。 その後, 臥位で主に深部に残在している再現痛を探し 基本手技で消失させる。原因筋線維は, 主に中殿笳, 大 殿筋, 最長筋, 腸肋筋, 多裂筋, 腸腰筋, 腰方形筋にあ る。その他, 股関節の左右の筋力差を検査し弱い方の 主動筋の触察で生じた筋痛, または原因筋線維の連結 筋を触察し出現した筋痛を消失させる。下肢の痺れは, 主に中殿筋, 大殿筋, 最長筋, 腸肋筋, 多裂筋, 腸腰筋 の触察で再現痺れを探す。さらに, 痺れが生じている 部位まで同様に探していき, 基本手技で改善する。䅡
椎椎間板ヘルニアと頝部痛に対する施行方法は, 腰部 と同様である。原因筋線維は, 第6 頸椎〜頭部までの伸 筋群のにあることが多い。上肢の痺れは, 主に棘下筋, 小円筋, 大円筋, 上腕三頭筋の触察で再現痺れが出現 する。その後, 痺れが生じている部位まで再現痺れを 探していき，基本手技で改善する。

3. 変形性股関節症, 変形性膝関節症, 股関節周囲および 膝関節周囲の痛み

変形性の股関節症や膝関節症は，股または膝関節の 変形によるストレスにより 2 次的に起こる侵害受容性 疼痛を改善する。変形性股関節症と股関節周囲の痛み では，主に大殿筋，中殿筋，腸腰筋，梨状筋，内転筋 群，大腿筋膜張筋，大腿直筋に原因筋線維がある。特 に大転子付着部付近で股関節の痛みの原因筋線維を確 定し治療することが重要である。

変形性膝関節症や膝関節周囲の痛みは, 主に大腿四 頭筋, 䣸足, 大腿筋膜張筋, 八ムストリングス, 䊫窩 笳，下腿三頭筋，前脛骨筋に原因筋線維がある。特に 膝蓋骨〜上下約 $10 \mathrm{~cm} の$ 範囲の筋, 膝蓋骨外縁の裏側お よび付着部, 黛足, 膝関節後面の触察により再現痛が 出現することが多い。

\section{4. 関節可動域制限}

まず, 収縮痛および短縮痛を探し基本手技で改善し， 最後に伸張される筋の痛みを触察で探し改善する。例 えば, 膝関節屈曲制限では自動介助運動で膝関節を屈 
曲させ，屈筋の中の再現痛（収縮筋）を探し治療する。 最後に大腿四頭筋を検查し治療する。他の関節も同様 に施行する。

5. 五十肩, 結帯動作の障害, リュウマチおよびその他の 痛み

腰部，頝部の痛みに対する施行法と同様の手順およ び方法で実施する。患者が訴えている安静時痛, 運動 時痛, ADL で起こる再現痛を探し改善する。

\section{引用文献}

1) 内野滋雄 (事業統括) 他: 平成18年度文部科学省「専修学校 教育重点支援プラン」委託事業「理学療法士養成課程への筋 調整法導入のための教育プログラム作成」，理学療法士養成 課程用MTAテキスト，1997。

2) 高田治実：マイオチューニングアプローチ．専門リハビリ
テーション, 2005, 4: 2-13.

3) 高田治実, 坂本 雄, 奥 壽郎・他 : 疼痛筋に対するス卜 レッチングの効果. 理学療法, 2004, 12: 1456-1467.

4) Melzack R, Wall PD: Pain mechanisms: a new theory. Science, 1965, 150: 971-979.

5) Melzack R, Walla PD: The Challenge of Pain. Basic Book, New York, 1982

6) Araki T, Ito K, Kurosawa M, et al.: Response of sympathetic nerve activity and catecholamine secretion to cutaneous stimulation in anesthetized rats. Neuroscience, 1984, 12: 289-299.

7) Oscasson O: Functional organization of olivary projection to the cerebellar anterior lobe. The Inferior Olivary Nucleus. Anatomy and Physiology, Courville J, et al. ed., Raven, New York, 1980, pp279-289.

8) Le Bars D, Dickenson AH, Besson J-M: Diffuse noxious inhibitory controls (DNIC). Effects on dorsal horn convergent neurons in the rat. Pain, 1979, 6: 283-304. 